\title{
Prevalence and associated factors of overweight and obesity among schoolchildren in Hanoi, Vietnam
}

Thuy Thi Phuong Pham¹, Yumi Matsushita ${ }^{2 *}$, Lien Thi Kim Dinh ${ }^{3}$, Thanh Van Do ${ }^{4}$, Thanh Thi The Nguyen, Anh Tuan Bui ${ }^{5}$, Anh Quoc Nguyen ${ }^{6}$ and Hiroshi Kajio ${ }^{7}$

\begin{abstract}
Background: The prevalence of overweight and obesity (OW/OB) has increased rapidly in Vietnam. This study aimed to elucidate the factors influencing OW/OB among secondary schoolchildren.

Method: A survey was conducted in January 2014 in four randomly selected state schools in two Hanoi urban districts, and 821 students in grade six (11-12 years old) participated. Definitions of OW/OB followed the World Health Organization standard cut-offs.
\end{abstract}

Results: Overall, $4.1 \%$ of children were underweight, $59.7 \%$ were normal weight, $17.1 \%$ were overweight, and $19.1 \%$ were obese. The odds of OW/OB were lowest among children whose parents had college/university degrees [father $(\mathrm{aOR}=0.65,95 \% \mathrm{Cl}: 0.42-1.00)$; mother ( $\mathrm{aOR}=0.63,95 \% \mathrm{Cl}: 0.41-0.97)]$ compared with those whose parents had only a primary education. Children with an OW/OB family history had an increased risk of OW/OB. Other associated factors include parental OW/OB and birth weight (BW). The odds of OW/OB were highest among children with parents with OW/OB [father $(\mathrm{aOR}=2.022,95 \% \mathrm{Cl}$ : 1.34-3.04); mother $(\mathrm{aOR}=2.83,95 \% \mathrm{Cl}$ : 1.51-5.30)] compared with those with normal-weight parents. Children with both parents having OW/OB [both parents $(\mathrm{aOR}=6.59,95 \% \mathrm{Cl}$ : 1.28-33.87) had the highest risk, followed by one parent ( $\mathrm{aOR}=2.22,95 \% \mathrm{Cl}: 1.50-3.27)]$ and then neither parent having OW/OB. Moreover, high-birth-weight children [BW $\geq 3500 \mathrm{~g}(\mathrm{aOR}=1.52,95 \% \mathrm{Cl}$ : 1.07-2.15)] had greater odds than did normal-birth-weight children.

Children who slept $11 \mathrm{~h}$ per day [8-11 h (aOR $=0.57,95 \% \mathrm{Cl}: 0.40-0.81)$ or more (aOR $=0.44,95 \% \mathrm{Cl}: 0.22-0.87)$ ] had lower OW/OB odds than those who slept $8 \mathrm{~h}$ or less. Children with specific positive lifestyle behaviours had lower risk of OW/OB than those who did not engage in positive lifestyle behaviours. The odds were lower among children who exercised for weight reduction $(\mathrm{OR}=0.16,95 \% \mathrm{Cl}$ : $0.11-0.23)$, lowered food intake $(\mathrm{aOR}=0.12,95 \% \mathrm{Cl}$ : $0.09-0.17$ ), and added vegetables to their diet ( $\mathrm{aOR}=0.26,95 \% \mathrm{Cl}: 0.19-0.35)$.

Conclusion: The results suggest that parents and children with OW/OB parents or a high BW should be educated to prevent OW/OB at an early stage. Positive lifestyle behaviours should be adopted by the students.

Keywords: Overweight, Obesity, Children, Prevalence, Vietnam

\footnotetext{
*Correspondence: ymatsushita@hosp.ncgm.go.jp

${ }^{2}$ Center for Clinical Sciences, National Center for Global Health and Medicine,

Tokyo, Japan

Full list of author information is available at the end of the article
}

(c) The Author(s). 2019 Open Access This article is distributed under the terms of the Creative Commons Attribution 4.0 International License (http://creativecommons.org/licenses/by/4.0/), which permits unrestricted use, distribution, and reproduction in any medium, provided you give appropriate credit to the original author(s) and the source, provide a link to the Creative Commons license, and indicate if changes were made. The Creative Commons Public Domain Dedication waiver (http://creativecommons.org/publicdomain/zero/1.0/) applies to the data made available in this article, unless otherwise stated. 


\section{Background}

Overweight and obesity (OW/OB) are global epidemics. A report from the WHO indicated that in 2016 more than $18 \%$ of children and adolescents aged 5-19 were overweight or obese worldwide [1]. In Vietnam, the prevalence of OW/OB among children has also increased rapidly. According to the Vietnamese National Surveillance survey in 2010, the rate of OW/OB among children under 5 years old in Vietnam was 5.6\% (6.5 and 4.2\% for urban and rural areas, respectively). The current rate is six times higher than it was in 2000 [2]. Obesity is a risk factor for noncommunicable diseases (NCDs), such as type 2 diabetes, hypertension, and coronary artery disease. In 2015, there were 3.5 million cases of diabetes, and it is estimated that approximately 53,458 deaths were attributed to diabetes in Vietnam [3]. Moreover, Vietnam was identified as a country with a high incidence of NCDs, which are responsible for approximately $73 \%$ of all deaths, accounting for more than 379,000 deaths per year. Over one-third of deaths associated with NCDs are caused by cardiovascular diseases $[4,5]$. Children whose parents are both obese have an $80 \%$ risk of developing obesity during their lifetime. If only one parent is obese, the child's risk declines to $40-50 \%[6,7]$. Controlling OW/OB and chronic diseases was recognized as an area of major importance by the Government of Vietnam. This is one of the six strategy areas of the National Nutrition Strategy for the period of 2011-2020 and the vision for 2030 that was signed by the Prime Minister of the Socialist Republic of Vietnam in February 2012 [8]. In Vietnam, there are several studies that examined the prevalence of $\mathrm{OW} / \mathrm{OB}$ among children less than 10 years old; however, very few studies have been conducted with children 11-12 years old (grade 6). According to the National Institute of Diabetes and Digestive and Kidney Diseases, the National Institutes of Health, children in 6th grade (secondary school) are generally 12 years old and in early adolescence. This is a time of both physical and metabolic, as well as emotional and mental, growth and development. Children are assuming more responsibility for their own choices [9]. Additionally, in meta-analysis articles related to the prevalence of overweight and obesity in Asia and in the world, data about the OW/OB status of children at this age in Vietnam were not shown $[10,11]$. The present study aimed to determine the prevalence of OW/OB among secondary school children in Hanoi, Vietnam and to evaluate the factors that influence $\mathrm{OW} / \mathrm{OB}$ in this population. The findings of this study will contribute to a recommendation to Vietnamese schools for an educational programme to promote healthy lifestyle behaviours.

\section{Methods}

A cross-sectional survey was conducted in January 2014. Using a stratified sampling method, two districts were randomly selected from four urban districts in Hanoi, and then four state junior high schools were randomly selected from those two urban districts. In each school, five classes of grade six (11-12 years) were randomly selected, and all the students and their parent(s) in the selected classes were invited to participate in the study. The parents and students were required to provide written consent to participate in the study.

Each consent form required the signatures of the student and their parent(s) to enable participation; to participate, both the student and his/her parent must sign the consent form.

Students were given a self-administered questionnaire investigating their physical activity and nutrition (detail of the questionnaires in Additional file 1). They completed the questionnaires while sitting in their own classrooms and had $30 \mathrm{~min}$ to answer all the questions. Beforehand, public health professionals explained the details of the questionnaire and the purpose of the survey to the students.

Health examination and anthropometric measurements: Two groups, each including two doctors and three nutritionists, measured the weight of each student using BS-150WT digital weighing scales (Dretec, Koshigaya, Japan), which are precise to within $100 \mathrm{~g}$ [12]. Students were requested to remove their shoes and all heavy clothing. Height measurements were performed using standard metres with a precision of $0.1 \mathrm{~cm}$; the metres were placed vertically, i.e., perpendicular to the ground. Students removed their sandals or shoes and then stood with their back against the metre while looking straight ahead and keeping their hands at their sides. An inelastic tape was used to measure the circumferences of the waist and hips. The results of height and circumferential measurements were recorded in centimetres to one decimal place [12]. Arterial blood pressure was measured using HEM-7051 electronic sphygmomanometers (Omron, Kyoto, Japan) [13].

Body mass index (BMI)-for-age was calculated using the formula $\mathrm{m} / \mathrm{h}^{2}$, and BMI was categorized following the $\mathrm{WHO}$ guidelines for $\mathrm{BMI}$ in children aged between 5 and 19 years [14].

Information on parental anthropometric measurements, family history, and environmental factors was collected by distributing questionnaires to the students' parent(s) (see Additional file 2). Because each student who participated in the study was weighed using BS150WT digital weighing scales (Dretec), the same weighing scales were also used to measure the parents' weights. To ensure the same tool measured weight and to benefit the participants of the study, all students were provided a BS-150WT digital scale. The research group provided instructions on adhesive-backed papers to 
instruct parents about the correct way to measure their height. The data were then recorded in the questionnaires by the students' parent(s). Parents who had a BMI $\geqq 25 \mathrm{~kg} / \mathrm{m}^{2}$ were considered to have OW/OB based on the WHO standard cut-off points [15].

\section{Biochemical data}

Laboratory tests were conducted in the Biochemistry Department of Bach Mai Hospital, Hanoi, Vietnam according to the ISO 15189 standard.

Students were instructed to skip breakfast on the day of the examination and had to fast for at least $10 \mathrm{~h}$. The adequacy of the fasting period was confirmed before blood samples were collected. Venous blood ( $5 \mathrm{ml} /$ student) was collected between 7:30-10:00 AM by nurses who were working in the Pediatric Department of Bach Mai Hospital in $1 \mathrm{~g} / \mathrm{L}$ tubes containing ethylenediaminetetraacetic acid as an anticoagulant, and the samples were placed on dry ice. The samples were then transported from the study site to the Biochemistry Department of Bach Mai Hospital. They were centrifuged at $5000 \mathrm{rpm}$ for $10 \mathrm{~min}$. Plasma glucose was determined using the glucose hexokinase method with a Cobas 8000 (c702) chemistry analyser (Roche, Basel, Switzerland). HbA1C was measured using the boronate affinity high-performance liquid chromatography method with an Ultra ${ }^{2}$ chromatograph (Primus Diagnostics, Kansas City, MO, USA). Insulin was determined using an electrochemiluminescence immunoassay with a Cobas $^{\circ} 8000$ (e170) chemistry analyser (Roche). Triglycerides, cholesterol, high-density lipoprotein, and low-density lipoprotein were measured using an automated colorimetric enzyme assay with a Cobas $^{\circ} 8000$ (e702) chemistry analyser (Roche).

\section{Statistical analysis}

Data analysis was performed using SPSS statistics desktop version 21.0 media pack software (IBM, Armonk, NY, USA). We used a simple chi-square test at the $\alpha=0.05$ level of significance to test the associations of different risk factors. Variables showing significant associations with $\mathrm{OW} / \mathrm{OB}$ in children were further identified using a logistic regression test to determine the odds ratio (OR) and the 95\% CI. The risk factors for OW/OB were adjusted for sex, and multiple logistic regression analysis was used to determine the adjusted odds ratio (aOR) of each risk factor. In the analysis, there were two outcome variables: the $\mathrm{OW} / \mathrm{OB}$ variable included the combined data of overweight and obesity, and the other variable incorporated the remaining data, which were not related to OW/OB in children, as a reference.

\section{Ethical considerations}

The study protocol was approved by the Ethics Committee of Bach Mai Hospital, Hanoi, Vietnam with the decision letter Number 529 QD-BM on the 10th of May 2013 and the Ethics Committee of the National Center for Global Health and Medicine, Japan, with the number 1496 on the 1st of October 2013. Before the collection of questionnaire data and venous blood samples, information sheets and consent forms were distributed to parents and students by the schools. Students participating in the study agreed to provide written informed consent with written approval from their parent(s). All participants could withdraw from the study at any time without any threats or disadvantages.

\section{Results}

From four districts in central Hanoi, two districts containing a total of 29 state schools were selected. Four randomly selected schools agreed to participate in the study. Information sheets and consent forms were distributed to 936 students and their parents. After both the student and his/her parent signed the consent form, 821 students participated in the study. Table 1 shows the characteristics of the students. The proportions of the students in each BMI range were evaluated according to the WHO standards. The proportion of underweight children was the lowest (3.9\% of boys and $4.3 \%$ of girls). The proportions of boys (18.9\%) and girls (15.4\%) who were overweight did not differ significantly, $\chi^{2}=1.79, p=0.18$. However, the proportion of obese boys (32.4\%) was approximately four times higher than that of obese girls $(7.7 \%)$.

When comparing the measurements of BMI and waist circumference, it is apparent that there was a large gender difference in waist circumference (boys: $71.01 \pm 9.60 \mathrm{~cm}$, girls: $66.13 \pm 7.62 \mathrm{~cm}, p=0.001$ ) as well as in BMI (boys: $19.9 \pm 3.6 \mathrm{~kg} / \mathrm{m}^{2}$, girls: $18.49 \pm 2.87 \mathrm{~kg} / \mathrm{m}^{2}, p=0.001$ ).

As shown in Table 2, the biochemical data for total cholesterol and low-density lipoprotein also showed significant differences between boys and girls (total cholesterol: boys $4.33 \pm 0.78 \mathrm{mmol} / \mathrm{L}$, girls $4.20 \pm 0.72$ $\mathrm{mmol} / \mathrm{L}, p=0.012$; LDL boys $2.37 \pm 0.71 \mathrm{mmol} / \mathrm{L}$, girls $2.20 \pm 0.66, p=0.001 \mathrm{mmol} / \mathrm{L})$. Considering the family and children characteristics shown in Table 3, the odds of $\mathrm{OW} / \mathrm{OB}$ were lowest among children whose

Table 1 Prevalence for boys and girls

Proportions of boys and girls in each morphological category (based on BMI measurements)

\begin{tabular}{llllll}
\hline & $\begin{array}{l}\text { Underweight } \\
\%(n)\end{array}$ & $\begin{array}{l}\text { Normal } \\
\%(n)\end{array}$ & $\begin{array}{l}\text { Overweight } \\
\%(n)\end{array}$ & $\begin{array}{l}\text { Obesity } \\
\%(n)\end{array}$ & $\begin{array}{l}\text { Total } \\
(n)\end{array}$ \\
\hline $\begin{array}{l}\text { Boys } \\
(n=380)\end{array}$ & $3.9 \%(15)$ & $44.7 \%(170)$ & $18.9 \%(72)$ & $32.4 \%(123)$ & 380 \\
$\begin{array}{l}\text { Girls } \\
(n=441)\end{array}$ & $4.3 \%(19)$ & $72.6 \%(320)$ & $15.4 \%(68)$ & $7.7 \%(34)$ & 441 \\
Total & $4.1 \%(34)$ & $59.7 \%(490)$ & $17.1 \%(140)$ & $19.1 \%(157)$ & 821 \\
\hline
\end{tabular}

$P<0.001 ;$ chi square $=91.555$

Boys/girls presenting overweight or obesity: OR: 3.503 (95\% Cl: 2.60-4.73) 
Table 2 Anthropometric and laboratory data for boys and girls

\begin{tabular}{|c|c|c|c|c|}
\hline Factor & Sex & $n$ & Mean \pm SD & $P$ \\
\hline \multirow[t]{2}{*}{ BMI (kg/m2) } & boys & 380 & $19.90 \pm 3.60$ & \multirow[t]{2}{*}{0.001} \\
\hline & girls & 441 & $18.44 \pm 2.68$ & \\
\hline \multirow[t]{2}{*}{ Arm circumference $(\mathrm{cm})$} & boys & 376 & $23.51 \pm 3.19$ & \multirow[t]{2}{*}{0.001} \\
\hline & girls & 431 & $22.40 \pm 2.32$ & \\
\hline \multirow[t]{2}{*}{ Hip circumference $(\mathrm{cm})$} & boys & 379 & $81.67 \pm 7.89$ & \\
\hline & girls & 440 & $80.99 \pm 6.83$ & 0.192 \\
\hline \multirow[t]{2}{*}{ Waist circumference $(\mathrm{cm})$} & boys & 379 & $71.01 \pm 9.60$ & \multirow[t]{2}{*}{0.001} \\
\hline & girls & 440 & $66.13 \pm 7.62$ & \\
\hline \multirow{2}{*}{$\begin{array}{l}\text { Diastolic blood pressure } \\
(\mathrm{mmHg})\end{array}$} & boys & 379 & $70.48 \pm 10$ & \\
\hline & girls & 440 & $70.72 \pm 8.6$ & \multirow[t]{2}{*}{0.567} \\
\hline \multirow{2}{*}{$\begin{array}{l}\text { Systolic blood pressure } \\
(\mathrm{mmHg})\end{array}$} & boys & 379 & $111.09 \pm 10.3$ & \\
\hline & girls & 440 & $108.89 \pm 12.4$ & 0.170 \\
\hline \multirow[t]{2}{*}{ Glucose (mmol/L) } & boys & 380 & $4.85 \pm 0.52$ & \multirow[t]{2}{*}{0.048} \\
\hline & girls & 441 & $4.78 \pm 0.53$ & \\
\hline \multirow[t]{2}{*}{ T_cholesterol (mmol/L) } & boys & 380 & $4.33 \pm 0.78$ & \multirow[t]{2}{*}{0.012} \\
\hline & girls & 441 & $4.20 \pm 0.72$ & \\
\hline \multirow[t]{2}{*}{ Triglyceride (mmol/L) } & boys & 380 & $1.05 \pm 0.60$ & \multirow[t]{2}{*}{0.132} \\
\hline & girls & 441 & $1.11 \pm 0.54$ & \\
\hline \multirow[t]{2}{*}{ HDL_C (mmol/L) } & boys & 380 & $1.50 \pm 0.39$ & \multirow[t]{2}{*}{0.907} \\
\hline & girls & 441 & $1.49 \pm 0.40$ & \\
\hline \multirow[t]{2}{*}{ LDL_C (mmol/L) } & boys & 380 & $2.37 \pm 0.71$ & \multirow[t]{2}{*}{0.001} \\
\hline & girls & 441 & $2.20 \pm 0.66$ & \\
\hline \multirow[t]{2}{*}{$\mathrm{HbA1c}(\%)$} & boys & 380 & $5.44 \pm 0.26$ & \multirow[t]{2}{*}{0.362} \\
\hline & girls & 441 & $5.42 \pm 0.24$ & \\
\hline
\end{tabular}

parents had college / university degrees [father $(\mathrm{aOR}=$ 0.65, 95\% CI: 0.42-1.00); mother ( $\mathrm{aOR}=0.63$, 95\% CI: 0.41-0.97)] compared with those whose parents had only a primary education. Children with an $\mathrm{OW} / \mathrm{OB}$ family history had an increased risk of OW/OB. The odds were highest among children with parents with $\mathrm{OW} / \mathrm{OB}$ [father (aOR $=2.022,95 \% \mathrm{CI}: 1.34-3.04)$; mother $(\mathrm{aOR}=2.83,95 \% \mathrm{CI}: 1.51-5.30)$ ] compared with children whose parents had a normal weight. The associated factors included parental $\mathrm{OW} / \mathrm{OB}$, and the risk was the highest among children with both parents having overweight or obesity [both parents $(\mathrm{aOR}=$ 6.59, 95\% CI: $1.28-33.87$ ); one parent $(\mathrm{aOR}=2.22,95 \%$ CI: 1.50-3.27)] compared with those with neither parent having overweight or obesity. Regarding birth weight $(\mathrm{BW})$, the odds were greatest for high-birthweight children [children with a BW 3500 g or greater ( $\mathrm{aOR}=1.52$, 95\% CI: 1.07-2.15)] compared with those with a normal BW.

Regarding length of sleep, the odds of OW/OB were lowest among children who slept more than $11 \mathrm{~h}$ per day [sleeping 8-11 h (aOR $=0.57,95 \% \mathrm{CI}: 0.40-0.81)$ ], followed by those who slept between 8 and $11 \mathrm{~h}$
$[(\mathrm{aOR}=0.44,95 \% \mathrm{CI}: 0.22-0.87)]$ compared with those who slept less than $8 \mathrm{~h}$.

Children with specific positive lifestyle behaviours had lower risks for OW/OB. Furthermore, the odds of developing OW/OB was lower among children who exercised for weight reduction ( $\mathrm{aOR}=0.16,95 \% \mathrm{CI}$ : 0.11-0.23), lowered food intake (aOR $=0.12,95 \% \mathrm{CI}: 0.09-0.17$ ), and added vegetables to their diet $(\mathrm{aOR}=0.26,95 \% \mathrm{CI}$ : 0.19-0.35).

\section{Discussion}

The study identified the prevalences of overweight (17.1\%) and obesity (19.1\%) among schoolchildren aged 11-12 years in central Hanoi from a survey conducted in 2014, and the prevalences were higher than the national averages. A prior survey of the nutritional status of children in primary schools within urban areas of Hanoi was conducted by the Vietnam National Institute of Nutrition in 2011. That previous survey included participants aged 7-9 years and found rates of overweight and obesity of 23.4 and $17.3 \%$, respectively [16]. Another study in 2010 that included adolescents aged 11-14 years old in Ho Chi Minh City found rates of overweight and obesity of 19.6 and $7.9 \%$, respectively [17]. Obesity is a risk factor for NCDs, and Vietnam has been identified as a country with a major problems associated with NCDs, which are responsible for approximately $73 \%$ of total deaths [5]. There are several studies about the risk factors for OW/OB in Vietnam. A study performed in central Vietnam showed that BMI was the largest contributor to diabetes mellitus risk, with an OR of more than ten times compared to low- and normalBMIs [18]. Therefore, preventing OW/OB in children plays an important role in preventing NCDs in the future.

In addition to determining the prevalence of $\mathrm{OW} /$ $\mathrm{OB}$, our study resulted in several other findings. Children of parents with college or university degrees had the lowest risks for OW/OB. Our result was concordant with those of previous studies. Many studies in developed countries, such as the USA, Brazil, France, Denmark, and Appalachia, showed similar results as ours [19-22]. However, there were opposite tendencies in Colombia and Kenya, where maternal education was positively related to child overweight and negatively associated with physical activity among children. The researchers suggested that there was a possibility that such relationships might be related to the developmental stage of different countries [19].. Antonogeorgos G, et al. suggested that parental education status seemed to play a mediating role in the beneficial effect of diet on children's obesity status [19]. Our results suggested that education for parents could be effective for reducing $\mathrm{OW} / \mathrm{OB}$ among children in Vietnam. 
Table 3 Factors associated with overweight or obesity among children aged 11-12 years, Hanoi, Vietnam

\begin{tabular}{|c|c|c|c|c|c|c|c|c|}
\hline \multirow[t]{2}{*}{ Factor } & \multirow[t]{2}{*}{ OR } & \multicolumn{2}{|l|}{$95 \% \mathrm{Cl}$} & \multirow[t]{2}{*}{$p$} & \multirow[t]{2}{*}{$\mathrm{aOR}$} & \multicolumn{2}{|l|}{$\underline{95 \% \mathrm{Cl}}$} & \multirow[t]{2}{*}{$p$} \\
\hline & & Lower & Upper & & & Lower & Upper & \\
\hline \multicolumn{9}{|l|}{ FAMILY CHARACTERISTICS } \\
\hline \multicolumn{9}{|l|}{ Father's education } \\
\hline Primary school & 1 & & & & 1 & & & \\
\hline Secondary school & 0.80 & 0.15 & 4.23 & 0.801 & 0.72 & 0.12 & 4.32 & 0.715 \\
\hline College or university & 0.73 & 0.48 & 1.09 & 0.122 & 0.65 & 0.42 & 1.00 & 0.050 \\
\hline \multicolumn{9}{|l|}{ Mother's education } \\
\hline Primary school & 1 & & & & 1 & & & \\
\hline Secondary school & 1.62 & 0.46 & 5.68 & 0.448 & 1.14 & 0.30 & 4.31 & 0.842 \\
\hline College or university & 0.69 & 0.46 & 1.04 & 0.079 & 0.63 & 0.41 & 0.97 & 0.037 \\
\hline \multicolumn{9}{|l|}{ Father's BMI } \\
\hline $18.5-24.9$ & 1 & & & & 1 & & & \\
\hline$<18.5$ & 0.66 & 0.29 & 1.45 & 0.317 & 0.62 & 0.26 & 1.44 & 0.265 \\
\hline$\geq 25$ & 1.92 & 1.30 & 2.84 & 0.001 & 2.02 & 1.34 & 3.04 & $<0.001$ \\
\hline \multicolumn{9}{|l|}{ Mother's BMI } \\
\hline $18.5-24.9$ & 1 & & & & 1 & & & \\
\hline$<18.5$ & 0.68 & 0.28 & 1.63 & 0.368 & 0.69 & 0.28 & 1.72 & 0.428 \\
\hline$\geq 25$ & 2.28 & 1.26 & 4.13 & 0.007 & 2.83 & 1.51 & 5.30 & 0.001 \\
\hline \multicolumn{9}{|l|}{$\begin{array}{l}\text { Parental overweight or obesity } \\
\text { (classified by BMI) }\end{array}$} \\
\hline Neither parent overweight or obese & 1 & & & & 1 & & & \\
\hline One parent overweight or obese & 1.94 & 1.35 & 2.80 & 0.001 & 2.22 & 1.50 & 3.27 & $<0.001$ \\
\hline Both parents overweight or obese & 7.18 & 1.50 & 34.89 & 0.015 & 6.59 & 1.28 & 33.87 & 0.024 \\
\hline \multicolumn{9}{|l|}{ CHILD CHARACTERISTICS } \\
\hline \multicolumn{9}{|l|}{ Number of siblings in the family } \\
\hline 1 & 1 & & & & 1 & & & \\
\hline 2 & 1.27 & 0.79 & 2.04 & 0.323 & 1.29 & 0.79 & 2.11 & 0.305 \\
\hline$\geq 3$ & 0.66 & 0.33 & 1.26 & 0.202 & 0.87 & 0.43 & 1.75 & 0.697 \\
\hline \multicolumn{9}{|l|}{ Birth order among siblings } \\
\hline 1 & 1 & & & & 1 & & & \\
\hline 2 & 0.89 & 0.66 & 1.19 & 0.420 & 0.80 & 0.58 & 1.09 & 0.149 \\
\hline$\geq 3$ & 0.40 & 0.16 & 1.00 & 0.050 & 0.47 & 0.18 & 1.22 & 0.122 \\
\hline \multicolumn{9}{|l|}{ Breastfeeding history (none as reference) } \\
\hline $\begin{array}{l}\text { Breastfed by mother for at least } \\
6 \text { months after birth }\end{array}$ & 0.80 & 0.58 & 1.12 & 0.191 & 0.87 & 0.62 & 1.22 & 0.410 \\
\hline \multicolumn{9}{|l|}{ Birth weight (grams) } \\
\hline $2500-3500$ & 1 & & & & 1 & & & \\
\hline$<2500$ & 0.40 & 0.18 & 0.87 & 0.021 & 0.51 & 0.22 & 1.14 & 0.101 \\
\hline$\geq 3500$ & 1.60 & 1.14 & 2.23 & 0.006 & 1.52 & 1.07 & 2.15 & 0.019 \\
\hline \multicolumn{9}{|l|}{$\begin{array}{l}\text { Time spent watching television } \\
\text { (hours per day) }\end{array}$} \\
\hline$<2$ & 1 & & & & 1 & & & \\
\hline $2-4$ & 0.97 & 0.67 & 1.41 & 0.862 & 1.00 & 0.68 & 1.49 & 0.989 \\
\hline$>4$ & 1.56 & 0.89 & 2.72 & 0.122 & 1.78 & 0.99 & 3.20 & 0.056 \\
\hline
\end{tabular}

Sleep per day (hours) 
Table 3 Factors associated with overweight or obesity among children aged 11-12 years, Hanoi, Vietnam (Continued)

\begin{tabular}{|c|c|c|c|c|c|c|c|c|}
\hline \multirow[t]{2}{*}{ Factor } & \multirow[t]{2}{*}{ OR } & \multicolumn{2}{|l|}{$95 \% \mathrm{Cl}$} & \multirow[t]{2}{*}{$p$} & \multirow[t]{2}{*}{$\mathrm{aOR}$} & \multicolumn{2}{|c|}{$95 \% \mathrm{Cl}$} & \multirow[t]{2}{*}{$p$} \\
\hline & & Lower & Upper & & & Lower & Upper & \\
\hline$<8$ & 1 & & & & 1.00 & & & \\
\hline $8-11$ & 0.64 & 0.46 & 0.90 & 0.009 & 0.57 & 0.40 & 0.81 & $<0.001$ \\
\hline$>11$ & 0.47 & 0.24 & 0.90 & 0.022 & 0.44 & 0.22 & 0.87 & 0.018 \\
\hline \multicolumn{9}{|l|}{$\begin{array}{l}\text { PHYSICAL ACTIVITY AND LIFESTYLE } \\
\text { BEHAVIOURS OF CHILDREN }\end{array}$} \\
\hline \multicolumn{9}{|l|}{$\begin{array}{l}\text { Exercised in last } 7 \text { days ( } 0-2 \text { days/week as } \\
\text { reference compared with those who did } \\
3 \text { days or more per week) }\end{array}$} \\
\hline Exercised for 60 min per day & 1.19 & 0.87 & 1.63 & 0.276 & 0.96 & 0.69 & 1.34 & 0.83 \\
\hline $\begin{array}{l}\text { Intense exercise for } 20 \text { min per day } \\
\text { evidenced by sweating and breathing } \\
\text { hard }\end{array}$ & 1.15 & 0.82 & 1.62 & 0.411 & 0.97 & 0.68 & 1.37 & 0.84 \\
\hline $\begin{array}{l}\text { Participation in sports in the last } 12 \text { months } \\
\text { (None as reference) }\end{array}$ & 1.14 & 0.48 & 2.7 & 0.765 & 1.22 & 0.49 & 2.98 & 0.67 \\
\hline \multicolumn{9}{|l|}{ Lifestyle behaviours (None as reference) } \\
\hline Weight-reducing exercises & 0.17 & 0.12 & 0.23 & $<0.001$ & 0.16 & 0.11 & 0.23 & $<0.001$ \\
\hline Lowering food intake & 0.45 & 0.11 & 0.20 & $<0.001$ & 0.12 & 0.09 & 0.17 & $<0.001$ \\
\hline Adding vegetables to diet & 0.26 & 0.19 & 0.36 & $<0.001$ & 0.26 & 0.19 & 0.35 & $<0.001$ \\
\hline
\end{tabular}

Odds ratio (OR) by logistic regression univariate analysis

Ajusted OR by multivariate logistic regression analysis by each individual variable and controled for sex

We also found that parental OW/OB is a risk factor for OW/OB among children. This result is similar to the results of previous studies conducted in South Korea from 2007 to 2010 [23] and in the UK from 1998 to 2001 [24]. The study in the USA showed that among children, especially older children, obesity was an increasingly important predictor of adult obesity [6]. Therefore, it is vital to create a strategy for preventing OW/OB among children who have parents with OW/ OB. Those parents and children should emphasize healthy dietary habits and regular exercise from an early age. The study in the USA also showed that parental obesity was a risk factor for adult obesity among both obese and non-obese children [6]. A suitable educational programme should be implemented within schools as well as in communities to reduce the burden of $\mathrm{OW} / \mathrm{OB}$ among children and adults in the future.

Several studies have shown that breastfeeding contributes to preventing OW/OB in children [25-27]. Our study showed a similar trend; however, this finding did not reach statistical significance. One study from Scotland in 1999 reported that there was no association between breastfeeding and OW/OB among children [28].

According to a meta-analysis, most studies have concluded that BW is a factor that contributes to OW/OB $[29,30]$. A cohort study from Sicily in 2016 also supported this association [31]. Our present study additionally found that a BW of $3500 \mathrm{~g}$ or more was significantly positively associated with $\mathrm{OW} / \mathrm{OB}$ in Vietnamese children. A meta-analysis reported that pre-pregnancy OW/
$\mathrm{OB}$ in women increased the risk of high birth weight (HBW) and subsequent offspring OW/OB [31]. In addition, there have been several trials of interventions to reduce the risk of OW/OB in infancy and early childhood [31]. We suggest that an educational programme on weight management for pregnant women be conducted to prevent $\mathrm{OW} / \mathrm{OB}$ among children.

Many studies have shown that time spent watching television is associated with an increased risk of OW/ OB [32-35]. Our study also found a trend towards an increased risk of OW/OB among children who watched television for longer than $4 \mathrm{~h}$ per day, but this finding hardly reached statistical significance. It was suggested that time spent watching TV might be related to several mechanisms leading to OW/OB among children, such as decreased physical activity, increased energy intake, increased sedentary behaviour, exposure to food advertising and reduced sleep time [32-35]. Further investigation is necessary to clarify such relationships for the intervention of OW/OB among Vietnamese children.

The results of the study showed that the duration of sleeping was negatively associated with $\mathrm{OW} / \mathrm{OB}$ among children. This is the same result as that of a metaanalysis [36]. The data from a study in Portugal showed that the OR for childhood obesity decreased with sleep duration (reference 8 hours/day (h/d); 9-10h/d: 0.44; $\geqq 11 \mathrm{~h} / \mathrm{d}$ : 0.39) [37]. A meta-analysis of 12 studies including 15 cohorts showed that short sleep duration was significantly associated with obesity (relative risk 1.30, 95\% CI: $1.20-1.42$ ), even after the exclusion of 2 cohorts that 
substantially affected the heterogeneity [36]. Shorter night-time sleep could be associated with higher total energy intake [38] and less physical activity [39]. However, the precise mechanisms underlying the association between short sleep duration and obesity have not been elucidated. It was suggested that improvement in child sleep duration would have a positive impact on $\mathrm{OW} / \mathrm{OB}$ among children [40].

We evaluated self-perceived assessment of healthpromoting behaviours for lifestyle improvement among children. We obtained one important finding that selfefficacy of specific positive lifestyle behaviours was strongly associated with reduced risks of OW/OB among children. There are several studies reporting the associations between self-efficacy and obesity among children [41-46]. One study reported that there were no differences in physical activity between normal-fat and overfat children [41]. However, another study in Korea reported that there were differences in eating habits, physical activity, and self-efficacy between children with normal weight and OW/OB [42]. The researchers suggested that the increase in self-efficacy be one of the targets for obesity management programmes among children. It was reported that perceived physical selfefficacy and BMI were negatively associated among schoolchildren, suggesting the importance of the psychological aspect of obesity [43]. Another study reported that there were significant differences in healthy-eatingspecific self-efficacy levels between students of normal weight and those with OW/OB [44]. Additionally, children with high self-efficacy were reported to participate in significantly more physical activity than those with low self-efficacy [41]. In fact, there have been several intervention studies for the treatment of $\mathrm{OW} / \mathrm{OB}$ in children or adolescents [45, 46]. Several studies have suggested that parent and community involvement was effective in reducing the risk of obesity in schoolchildren [47-50]. At the ages of 11-12, children become capable of making independent decisions regarding their diet and can exercise to keep their body healthy. We think that this age range is the right time to start treating $\mathrm{OW} / \mathrm{OB}$ in children. Further investigation is needed to clarify the factors associated with self-efficacy and OW/ $\mathrm{OB}$ in children or adolescents to reduce the risk of obesity in children.

\section{Limitations}

This study has some limitations regarding the generalizability of our findings. First, this study was a cross-sectional study. Therefore, we could not address causal relationships of variables or factors related to obesity. The potential causal relationships must be clarified by longitudinal studies. Second, this study was limited to the urban area of Hanoi, and the results may not be applicable to all populations in Hanoi; however, the results could be a reference for large cities in Vietnam, such as Ho Chi Minh, Da Nang, and Hue cities. Further studies should include students in other areas with a focus on identifying lifestyle factors that can effectively prevent and treat $\mathrm{OW} / \mathrm{OB}$. Third, we did not investigate the factors associated with our findings. We found that children of parents with college or university degrees had the lowest risks for $\mathrm{OW} / \mathrm{OB}$ and that children who showed specific positive lifestyle behaviours had reduced risks of OW/OB. In the future, we need to conduct further investigations to clarify specific associated factors related to these findings. Finally, an effective educational programme should be implemented in schools to improve students' knowledge and induce behavioural changes that can contribute to reducing the prevalence of $\mathrm{OW} / \mathrm{OB}$ among children in urban and rural areas of Vietnam based on our findings.

\section{Conclusion}

The prevalences of OW/OB among 11- to 12-year-old students in central Hanoi were quite high compared with the data from other studies in Hanoi and Ho Chi Minh City in Vietnam [16, 17]. This study also found that several characteristics of the children, their families, and their lifestyle behaviours were strongly associated with the risks of OW/OB. The results suggested that parental education level might be associated with OW/ $\mathrm{OB}$ among children and that families with parents with OW/OB and children with a high BW should be educated to prevent $\mathrm{OW} / \mathrm{OB}$ at an early age. In addition, it is suggested that to reduce the prevalence of $\mathrm{OW} / \mathrm{OB}$ among children, targets for positive lifestyle changes should be set and managed by the students. Further studies should focus on the intervention and treatment of OW/OB among schoolchildren aged 11-12 years.

\section{Supplementary information}

Supplementary information accompanies this paper at https://doi.org/10. 1186/s12889-019-7823-9.

Additional file 1. Survey Questionnaire (for students).

Additional file 2. Questionnaire for parent.

\section{Abbreviations}

BMI: Body mass index; BW: Birth weight; Cl: Confidence interval;

ISO: International Organization for Standardization; NCDs: Non-

communicable diseases; OR: Odds ratio; OW/OB: Overweight and obesity; WHO: World Health Organization

\section{Acknowledgements}

We have obtained permission to publish full names of the people who contributed to our research and would like to express our sincere thanks to Professor Mitsuhiko Hara of the Department of Human Nutrition, Faculty of Human Nutrition, Tokyo Kasei Gakuin University, who provided us with valuable advice for performing the study; Phan Hung for his supportive English translation; Pham Thuy Linh for her general assistance; all the teachers, students, and parents from the four junior high schools that participated in this study; and to American Journal Experts for editing a draft of the manuscript. 


\section{Authors' contributions}

PTPT designed the study, wrote the proposal, organized and performed the study, analyzed the data, wrote the manuscript and edited the final manuscript for publication. YM provided statistical advice and corrected the manuscript. DTKL, DVT, NTTT provided advice in the design of the study, organized and performed the study, collected the data and discussed initial ideas for writing the manuscript. BTA set up and supervised the process of blood samples collection, treatment and preservation as well as performed laboratorial tests. NQA supervised the whole study. HK designed the study, wrote the proposal, supervised the whole study and edited the final manuscript for publication. All the authors have read and approved the final manuscript.

\section{Funding}

Grants were provided from the National Center for Global Health and Medicine $(2858,25 S 1)$ and Japan Agency for Medical Research and Development. The funders had no role in the study design, data collection and analysis, or manuscript writing.

\section{Availability of data and materials}

The datasets generated and/or analysed during the current study are not publicly available but are available from the corresponding author on reasonable request.

\section{Ethics approval and consent to participate}

The study protocol was approved by the Ethical Committee of Bach Mai Hospital, Hanoi, Vietnam, decision number: 529 QD-BM on May 10, 2013 and the Ethical Committee of the National Center for Global Health and Medicine, Japan, decision number: 1496 on October 1, 2013. Before the collection of questionnaire data and venous blood samples, information sheets and consent forms were distributed to parents and students by the schools. Students participating in the study agreed to provide written informed consent with written approval from their parent(s). All participants could withdraw from the study at any time without any threats or disadvantages.

\section{Consent for publication}

Not applicable.

\section{Competing interests}

The authors declare that they have no competing interests.

\section{Author details}

${ }^{1}$ NCGM-Bach Mai Hospital Medical Collaboration Center, Hanoi, Vietnam. ${ }^{2}$ Center for Clinical Sciences, National Center for Global Health and Medicine, Tokyo, Japan. ${ }^{3}$ Center of Nutrition of Bach Mai Hospital, Hanoi, Vietnam. ${ }^{4}$ International Department, Bach Mai Hospital, Hanoi, Vietnam. ${ }^{5}$ Biochemistry Department, Bach Mai Hospital, Hanoi, Vietnam. ${ }^{6}$ Bach Mai Hospital, Hanoi, Vietnam. 'Department of Diabetes, Endocrinology and Metabolism, Central Hospital, National Center for Global Health and Medicine, Tokyo, Japan.

Received: 17 July 2018 Accepted: 21 October 2019

Published online: 08 November 2019

\section{References}

1. World Health Organization. Global Health Observatory (GHO) data. 2016. https://www.who.int/gho/ncd/risk_factors/overweight_adolescents_text/en/. Accessed 10 Mar 2018

2. Vietnam National Institute of Nutrition, Ministry of Health and UNICEF. The National nutrition surveillance 2009-2010 in Vietnam. 2012. http:// viendinhduong.vn/FileUpload/Documents/3.\%20Bao\%20cao\%20tom\%2 0tat\%20Bao\%20cao\%20Tong\%20Dieu\%20Tra.pdf. Accessed 12 Feb 2013.

3. World Health Organization. The growing burden of diabetes in Viet Nam. 2016. http://www.wpro.who.int/vietnam/mediacentre/features/feature_ world_health_day_2016_vietnam/en/. Accessed 10 Mar 2018.

4. World Health Organization. Noncommunicable Diseases Progress Monitor 2015. http://apps.who.int/iris/bitstream/10665/184688/1/9789241509459_ eng.pdf?ua=1. Accessed 10 Mar 2018.

5. World Health Organization. Noncommunicable Diseases (NCD) Country Profiles. 2014. https://www.who.int/nmh/countries/2014/vnm_en.pdf?ua=1. Accessed 22 Feb 2018
6. Whitaker RC, Wright JA, Pepe MS, Seidel KD, Dietz WH. Predicting obesity in young adulthood from childhood and parental obesity. N Engl J Med. 1997; 337(13):869-73.

7. Sothern MS. Obesity prevention in children: physical activity and nutrition. Nutrition. 2004;20(7-8):704-8.

8. Prime Minister. National Nutrition Strategy period 2011-2020 and vision to 2030 which was issued by prime Minister of the Socialist Republic of Vietnam. 2012. Accessed 18 Aug 2013.

9. National Institute of Diabetes and Digestive and Kidney Diseases, National Institutes of Health. HEALTHY Prevention study group. Primary prevention trial protocol. 2008. http://www.healthystudy.org/files/Additional\%20Web\%2 ODocs/HEALTHY\%20public\%20website\%20protocol\%20v1_4\%20071408.pdf. Accessed 18 Aug 2013.

10. Caleyachetty R, Echouffo-Tcheugui JB, Tait CA, Schilsky S, Forrester T, Kengne AP. Prevalence of behavioural risk factors for cardiovascular disease in adolescents in low-income and middle-income countries: an individual participant data meta-analysis. Lancet. 2015;3(7):535-44.

11. Mazidi M, Banach M, Kengne AP, Lipid and Blood Pressure Meta-analysis Collaboration Group. Prevalence of childhood and adolescent overweight and obesity in Asian countries: a systematic review and meta-analysis. Arch Med Sci. 2018 Oct:14(6):1185-203.

12. Centers for Disease Control and Prevention, National Health and Nutrition Examination Survey III. Body Measurements (Anthropometry). 1988. https:// www.cdc.gov/nchs/data/nhanes/nhanes3/cdrom/nchs/manuals/anthro.pdf. Accessed 20 Jan 2014

13. Centers for Disease Control and Prevention, High blood pressure. Measuring Blood Pressure. 2014. https://www.cdc.gov/bloodpressure/measure.htm. Accessed 20 Jan 2014

14. World Health Organization. Growth reference 5-19 years. 2007. http://www. who.int/growthref/who2007_bmi_for_age/en/. Accessed 20 Jan 2014.

15. Centers for Disease Control and Prevention. About Adult BMI. 2013. https:// www.cdc.gov/healthyweight/assessing/bmi/adult_bmi/index.html. Accessed 20 Jan 2014.

16. Nhung BT, H p LT, Bình TQ, Khanh LNB, Mai LB, Anh NĐV, Lâm NT, Huy NĐ, Nam TT, Thanh DV, et al. Tình trạng dinh dư ng c a học sinh tiểu học tại nội thành Hà Nôi năm 2011. Tap chí Y hoc Dư phòng. 2013;1(136):49.

17. Nguyen PV, Hong TK, Hoang T, Nguyen DT, Robert AR. High prevalence of overweight among adolescents in Ho Chi Minh City, Vietnam. BMC Public Health. 2013;13(1):141.

18. Miyakawa M, Shimizu T, Van Dat N, Thanh P, Thuy PT, ANh NT, Chau NH, Matsushita $Y$, Kajio H, Mai VQ, et al. Prevalence, perception and factors associated with diabetes mellitus among the adult population in Central Vietnam: a population-based, cross-sectional seroepidemiological survey. BMC Public Health. 2017. article 298.

19. Muthuri SK, Onywera VO, Tremblay MS, Broyles ST, Chaput JP, Fogelholm M, Hu G, Kuriyan R, Kurpad A, Lambert EV, et al. Relationships between parental education and overweight with childhood overweight and physical activity in 9-11 year old children: results from a 12-country study. PLoS One. 2016;11(8):e0147746.

20. Apouey BH, Geoffard PY. Parents' education and child body weight in France: the trajectory of the gradient in the early years. Econ Hum Biol. 2016;20:70-89.

21. Matthiessen J, Stockmarr A, Fagt S, Knudsen VK, Biltoft-Jensen A. Danish children born to parents with lower levels of education are more likely to become overweight. Acta Paediatr. 2014;103(10):1083-8.

22. Wang L, Slawson DL, Relyea G, Southerland $J$, Wang Y. Prevalence of and risk factors for adolescent obesity in Southern Appalachia, 2012. Prev Chronic Dis. 2014;11:E222.

23. Lee HS, Duffey KJ, Kim Cl, Popkin BM. The relationship between family and child weight status by household structure in South Korea: 2007-2010. Nutr Diabetes. 2013;3:e73.

24. Reilly JJ, Armstrong J, Dorosty AR, Emmett PM, Ness A, Rogers I, Steer C, Sherriff A. Early life risk factors for obesity in childhood: cohort study. BMJ. 2005:330:1357.

25. Gillman MW, Rifas-Shiman SL, Camargo CA Jr, Berkey CS, Frazier AL, Rockett $\mathrm{HR}$, Field AE, Colditz GA. Risk of overweight among adolescents who were breastfed as infants. The JAMA Network. 2001:285(19):2461-7.

26. Grummer-Strawn LM, Mei Z, Centers for Disease Control and Prevention Pediatric Nutrition Surveillance System. Does breastfeeding protect against pediatric overweight? Analysis of longitudinal data from the Centers for Disease Control and Prevention pediatric nutrition surveillance system. Pediatrics. 2004;113(2):e81-6. 
27. von Kries R, Koletzko B, Sauerwald T, von Mutius E, Barnert D, Grunert $\mathrm{V}$, von Voss H. Breast feeding and obesity: cross sectional study. BMJ. 1999;319:147-50.

28. Armstrong J, Reilly JJ, Child Health Information Team. Breastfeeding and lowering the risk of childhood obesity. Lancet. 2002;359(9322):2003-4.

29. Camila ER, Francisco AGV. Birth weight and obesity in children and adolescents: a systematic review. Rev Bras Epidemiol. 2010;13(2):1-13.

30. Yu ZB, Han SP, Zhu GZ, Zhu C, Wang XJ, Cao XG, Guo XR. Birth weight and subsequent risk of obesity: a systematic review and meta-analysis. Obes Rev. 2011 Jul;12(7):525-42.

31. Parrino C, Vinciguerra F, La Spina N, Romeo L, Tumminia A, Baratta R, Squatrito S, Vigneri R, Frittitta L. Influence of early-life and parental factors on childhood overweight and obesity. J Endocrinol Investig. 2016;39(11): 1315-21.

32. Gortmaker SL, Must A, Sobol AM, Peterson K, Colditz GA, Dietz WH. Television viewing as a cause of increasing obesity among children in the United States, 1986-1990. Arch Pediatr Adolesc Med. 1996 Apr; 150(4):356-62.

33. Viner RM, Cole TJ. Television viewing in early childhood predicts adult body mass index. J Pediatr. 2005;147(4):429-35.

34. Peck T, Scharf RJ, Conaway MR, DeBoer MD. Viewing as little as 1 hour of TV daily is associated with higher change in BMI between kindergarten and first grade. Obesity. 2015;23(8):1680-6.

35. Zhang G, Wu L, Zhou L, Lu W, Mao C. Television watching and risk of childhood obesity: a meta-analysis. Eur J Pub Health. 2016;26(1):13-8.

36. Li L, Zhang S, Huang Y, Chen K. Sleep duration and obesity in children: a systematic review and meta-analysis of prospective cohort studies. J Paediatr Child Health. 2017 Apr;53(4):378-85.

37. Padez C, Mourão I, Moreira P, Rosado V. Prevalence and risk factors for overweight and obesity in Portuguese children. Acta Paediatr. 2005;94: 1550-7.

38. Fisher A, McDonald L, van Jaarsveld CH, Llewellyn C, Fildes A, Schrempft S, Wardle J. Sleep and energy intake in early childhood. Int J Obes. 2014;38: 926-9.

39. Schmid SM, Hallschmid M, Jauch-Chara K, Wilms B, Benedict C, Lehnert H, Born J, Schultes B. Short-term sleep loss decreases physical activity under free-living conditions but does not increase food intake under timedeprived laboratory conditions in healthy men. Am J Clin Nutr. 2009;90(6): 1476-82.

40. Yoong SL, Chai LK, Williams CM, Wiggers J, Finch M, Wolfenden L Systematic review and meta-analysis of interventions targeting sleep and their impact on child body mass index, diet, and physical activity. Obesity. 2016;24(5):1140-7.

41. Suton D, Pfeiffer KA, Feltz DL, Yee KE, Eisenmann JC, Carlson JJ. Physical activity and self-efficacy in Normal and over-fat children. Am J Health Behav. 2013;37(5):635-40.

42. Ha SA, Lee SY, Kim KA, Seo JS, Sohn CM, Park HR, Kim KW. Eating habits, physical activity, nutrition knowledge, and self-efficacy by obesity status in upper-grade elementary school students. Nutr Res Pract. 2016;10(6):597-605.

43. Carissimi A, Adan A, Tonetti L, Fabbri M, Hidalgo MP, Levandovski R, Natale $\checkmark$, Martoni M. Physical self-efficacy is associated to body mass index in schoolchildren. J Pediatr. 2017;93:64-9.

44. Steele MM, Daratha KB, Bindler RC, Power TG. The relationship between self-efficacy for behaviors that promote healthy weight and clinical indicators of adiposity in a sample of early adolescents. Health Educ Behav. 2011;38(6):596-602.

45. Al-Khudairy L, Loveman E, Colquitt JL, Mead E, Johnson RE, Fraser H, Olajide J, Murphy M, Velho RM, O'Malley C, et al. Diet, physical activity and behavioural interventions for the treatment of overweight or obese adolescents aged 12 to 17 years. Cochrane Database Syst Rev. 2017;6: CD012691.

46. Mead E, Brown T, Rees K, Azevedo LB, Whittaker V, Jones D, Olajide J, Mainardi GM, Corpeleijn E, O'Malley C, Beardsmore E, Al-Khudairy L, Baur L, Metzendorf MI, Demaio A, Ells $\sqcup$. Diet, physical activity and behavioural interventions for the treatment of overweight or obese children from the age of 6 to 11 years. Cochrane Database Syst Rev. 2017;22(6):CD012651.

47. Davidson Z, Simen-Kapeu A, Veugelers PJ. Neighborhood determinants of self-efficacy, physical activity, and body weights among Canadian children. Health Place. 2010;16(3):567-72.

48. Wright K, Norris K, Newman Giger J, Suro Z. Improving healthy dietary behaviors, nutrition knowledge, and self-efficacy among underserved school children with parent and community involvement. Child Obes. 2012;8(4):347-56

49. Lu W, McKyer EL, Lee C, Ory MG, Goodson P, Wang S. Children's active commuting to school: an interplay of self-efficacy, social economic disadvantage, and environmental characteristics. Int J Behav Nutr Phys Act. 2015;12:29.

50. Nock NL, levers-Landis CE, Dajani R, Knight D, Rigda A, Narasimhan S, Uli N. Physical activity self-efficacy and fitness: family environment relationship correlates and self-esteem as a mediator among adolescents who are overweight or obese. Child Obes. 2016;12(5):360-7.

\section{Publisher's Note}

Springer Nature remains neutral with regard to jurisdictional claims in published maps and institutional affiliations.
Ready to submit your research? Choose BMC and benefit from:

- fast, convenient online submission

- thorough peer review by experienced researchers in your field

- rapid publication on acceptance

- support for research data, including large and complex data types

- gold Open Access which fosters wider collaboration and increased citations

- maximum visibility for your research: over $100 \mathrm{M}$ website views per year

At BMC, research is always in progress.

Learn more biomedcentral.com/submissions 